\title{
Corrigendum: Subcutaneous Immunization of Dogs With Bordetella bronchiseptica Bacterial Ghost Vaccine
}

\section{OPEN ACCESS}

Approved by:

Frontiers Editorial Office,

Frontiers Media SA, Switzerland

*Correspondence:

Abbas Muhammad

abbas.muhammad@bird-c.at

Specialty section

This article was submitted to

Mucosal Immunity,

a section of the journal

Frontiers in Immunology

Received: 23 January 2020

Accepted: 24 January 2020

Published: 12 February 2020

Citation:

Muhammad A, Kassmannhuber J, Rauscher M, Falcon AA, Wheeler DW,

Zhang AA, Lubitz $P$ and Lubitz $W$ (2020) Corrigendum: Subcutaneous Immunization of Dogs With Bordetella bronchiseptica Bacterial Ghost Vaccine. Front. Immunol. 11:193. doi: 10.3389/fimmu.2020.00193

\begin{abstract}
Abbas Muhammad ${ }^{1 *}$, Johannes Kassmannhuber ${ }^{1,2}$, Mascha Rauscher ${ }^{1,2}$, Alaric A. Falcon ${ }^{3}$, David W. Wheeler ${ }^{3}$, Alan A. Zhang ${ }^{3}$, Petra Lubitz ${ }^{1}$ and Werner Lubitz ${ }^{1}$

${ }^{1}$ BIRD-C GmbH \& Co KG, Vienna, Austria, ${ }^{2}$ Centre of Molecular Biology, University of Vienna, Vienna, Austria, ${ }^{3}$ ELANCO Animal Health, Greenfield, IN, United States
\end{abstract}

Keywords: Bordetella, Bacterial Ghosts (BGs), whooping cough, immunization (vaccination), dog model

\section{A Corrigendum on}

Subcutaneous Immunization of Dogs With Bordetella bronchiseptica Bacterial Ghost Vaccine by Muhammad, A., Kassmannhuber, J., Rauscher, M., Falcon, A. A., Wheeler, D. W., Zhang, A. A., et al. (2019). Front. Immunol. 10:1377. doi: 10.3389/fimmu.2019.01377

An author name was incorrectly spelled as Mascha Raucher. The correct spelling is Mascha Rauscher.

The authors apologize for this error and state that this does not change the scientific conclusions of the article in any way. The original article has been updated.

Copyright (๑) 2020 Muhammad, Kassmannhuber, Rauscher, Falcon, Wheeler, Zhang, Lubitz and Lubitz. This is an open-access article distributed under the terms of the Creative Commons Attribution License (CC BY). The use, distribution or reproduction in other forums is permitted, provided the original author(s) and the copyright owner(s) are credited and that the original publication in this journal is cited, in accordance with accepted academic practice. No use, distribution or reproduction is permitted which does not comply with these terms. 